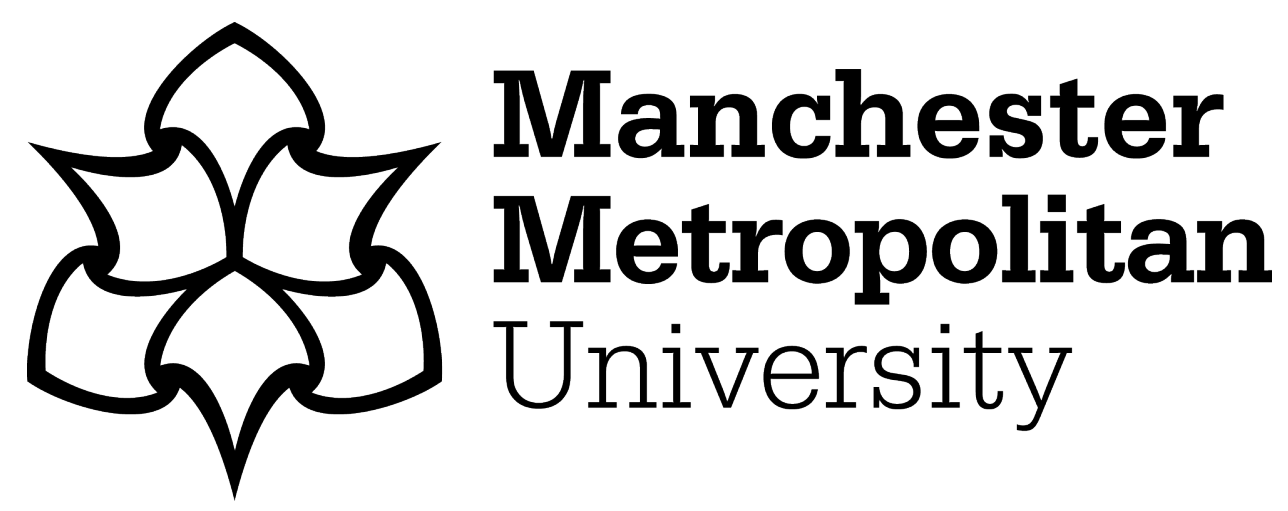

Devenish, Christian ORCID logoORCID: https://orcid.org/0000-0002-52490844, Lees, Alexander C, Collar, Nigel J and Marsden, Stuart J (2021) Multidecadal land use impacts across the vast range of an iconic threatened species. Diversity and Distributions, 27 (11). pp. 2033-2296. ISSN 13669516

Downloaded from: https://e-space.mmu.ac.uk/628242/

Version: Published Version

Publisher: Wiley

DOI: https://doi.org/10.1111/ddi.13395

Usage rights: Creative Commons: Attribution 4.0

Please cite the published version 


\title{
Multi-decadal land use impacts across the vast range of an iconic threatened species
}

\author{
Christian Devenish $^{1}$ (D) | Alexander C. Lees ${ }^{1,2}$ | Nigel J. Collar ${ }^{3}$ | Stuart J. Marsden ${ }^{1}$
}

${ }^{1}$ Ecology and Environment Research Centre, Department of Natural Sciences, Manchester Metropolitan University, Manchester, UK

${ }^{2}$ Cornell Lab of Ornithology, Cornell University, Ithaca, NY, USA

${ }^{3}$ BirdLife International, Cambridge, UK

\section{Correspondence}

Christian Devenish, Ecology and

Environment Research Centre, Department of Natural Sciences, Manchester Metropolitan University, Manchester, UK.

Email: c.devenish@mmu.ac.uk

Funding information

Parrot Wild Life Foundation

Editor: Ana Benítez López

\begin{abstract}
Aim: To explore spatiotemporal changes in Hyacinth Macaw Anodorhynchus hyacinthinus distribution and the impacts of land use change over 25 years, across its vast range in central/eastern South America.

Location: Brazil, Bolivia and Paraguay, South America, covering almost 3 million $\mathrm{km}^{2}$. Methods: We use a novel, multi-temporal species distribution model, to combine both year-specific occurrence records and land use/cover data in a single model that is subsequently projected over a land cover time series. We investigate changes in geographic range over 25 years and potential drivers of range extent at multiple spatial scales (10 and $30 \mathrm{~km}$ ) and time-lags (current and 10 years previously). We also assess protected area coverage and impacts from degazettement within the remaining range and highlight priority areas to search for undiscovered populations.

Results: The modelled range of the species increased by $75,000 \mathrm{~km}^{2}$ to over $500,000 \mathrm{~km}^{2}$ between 1995 and 2019, during which period agriculture and pasture increased by $600,000 \mathrm{~km}^{2}$ within the species' extent of occurrence. Habitat suitability was influenced most strongly by distribution of palms, forest cover and changes in pasture over 10 years and usually by predictors measured at larger spatial scales. Just $8 \%$ of the macaw's modelled range falls within protected areas, and more than $20,500 \mathrm{~km}^{2}$ of protected areas overlapping with the range have been degazetted in the last 40 years. We highlight key areas to search for undiscovered populations in under-sampled and remote areas, especially led by community citizen science initiatives involving indigenous groups and protected area staff.

Main conclusions: Novel modelling methods, combining multi-temporal occurrence records and land cover data, appropriate for small sample sizes per year, have revealed habitat dynamics and changes to the range of this threatened species over 25 years. The method may have wide applicability for a range of species, including elusive and poorly studied species.

KEYWORDS

Brazil, Hyacinth Macaw Anodorhynchus hyacinthinus, land cover classification, land use change, protected areas, species distribution
\end{abstract}

This is an open access article under the terms of the Creative Commons Attribution License, which permits use, distribution and reproduction in any medium, provided the original work is properly cited.

(c) 2021 The Authors. Diversity and Distributions published by John Wiley \& Sons Ltd. 


\section{1 | INTRODUCTION}

Conservation biology faces huge challenges in regions that are species-rich but data-poor (Richardson \& Whittaker, 2010). Vital species-specific metrics such as extent of occurrence, area of occupancy, population size and trajectory, which correlate strongly with extinction risk (IUCN, 2016), are lacking for vast numbers of species and are particularly difficult to obtain in large-ranged taxa that cross biogeographic and political boundaries (Shaney et al., 2017). Increasingly, however, statistical modelling methods, together with data sources from remote sensors and citizen science, are being used to supplement sparse existing information (Lang et al., 2015). The proliferation of remote-sensed and land cover predictors in species distribution models (Bradley \& Fleishman, 2008; He et al., 2015), facilitated by cloud-based platforms such as Google Earth Engine, have paved the way for the incorporation of time series analysis into species modelling (Amiri et al., 2020; Cord \& Rödder, 2011; Radeloff et al., 2019). Remote-sensed data play a crucial role in mapping land conversion to agriculture, one of the prime threats facing vertebrates (Hoffmann et al., 2010). New land cover products, illuminating relationships between land use changes and species occurrence patterns at both regional (mapBiomas Project, 2019) and global scales (Chen et al., 2015; Hansen et al., 2013), are therefore crucial additions to the conservation toolbox. Although there is a rising interest in the use of metrics from species distribution models, such as extent of occurrence, to evaluate extinction risk (Syfert et al., 2014), challenges remain in the use of time series of predictors, either directly from remote sensing, or classified land cover to infer changes in range size over time (Breiner et al., 2017). Metrics representing changes in population or range size are fundamental to the IUCN Red List criteria (IUCN, 2016) and crucial data gaps remain, especially in large-ranged, hard-to-study species.

The Hyacinth Macaw Anodorhynchus hyacinthinus, the world's largest parrot, has a distribution that spans $2,850,000 \mathrm{~km}^{2}$ in mainly data-poor and sometimes largely inaccessible regions of Brazil, Paraguay and Bolivia (BirdLife International, 2019). Its range cuts across biogeographical provinces with very different topography, vegetation and climate (Collar et al., 1992), including the Pantanal, Cerrado and Amazonia biomes, in each of which the species holds genetically distinct populations (de Almeida et al., 2019; Faria et al., 2008; Presti et al., 2015). In the past hundred years, its population has declined due to exploitation for the pet trade and feather ornamentation and because of the impacts of habitat loss, fragmentation and degradation (Collar et al., 1992; Faria et al., 2008; Machado et al., 2008). Its patchy distribution in remote and inaccessible habitats, high daily and seasonal mobility, and longevity have impeded research aimed at understanding its conservation status and needs. Its diet ties it to a number of palm species; it depends heavily on Sterculia apetala trees for nest sites, and it shows a clear preference for open wooded, riparian and forest-edge habitats, often near pastures (Guedes, 2004; Pinho \& Nogueira, 2003; Scherer-Neto et al., 2019; da Silva et al., 2019; Tella et al., 2020; Yamashita, 1997), but the precise factors governing its responses to land use change, and how these might differ in different parts of its huge range, are unknown (BirdLife International, 2019). Nevertheless, owing to population increases in the Pantanal (e.g. Pinho \& Nogueira, 2003; Scherer-Neto et al., 2019), where it is a major draw for ecotourists and in places managed accordingly, the Hyacinth Macaw was downgraded to Least Concern on the Brazilian Red List of threatened species (ICMBio, 2018; Machado et al., 2008) and from Endangered to Vulnerable on the global IUCN Red List (BirdLife International, 2019). These changes in designated status may technically have been justified; however, the Pantanal represents $<7 \%$ of the species' historical range in Brazil, and there remains uncertainty about the status of all other populations, particularly given their recently demonstrated mutualism with palm species (Tella et al., 2020). If these populations are to be protected and their conservation status improved, then the first requirement is to clarify their current extent, the status of the habitats they occupy and the likelihood that undetected populations exist outside its known range.

We seek to address these knowledge gaps using multi-temporal land use/cover data within a species distribution model framework, aimed at unravelling relationships with land use change across space and time. Specifically, we ask: (1) How have land use dynamics over the last 30 years affected occupancy within its range and over what spatial and decadal scales have these acted? (2) How has the range of the Hyacinth Macaw changed within the Pantanal, Cerrado and Amazonia biomes over this time period? (3) What are the remaining knowledge gaps, in terms of possible undiscovered populations, and management gaps, in terms of effective protected areas?

\section{2 | METHODS}

\section{1 | Species distribution modelling}

We employed a novel modelling approach to create a single distribution model from multi-annual, high-resolution land use/cover data and palm species habitat suitability. From this model, we infer the importance of spatial and temporal landscape dynamics in determining distribution, as well as gauging changes in distribution across the Pantanal, Cerrado and Amazonia biomes over 25 years.

\subsection{1 | Species occurrence records}

We collated 4,157 Hyacinth Macaw occurrence data points (Table S1a, S1b in supporting information) from four main sources: (a) ICMBio (5\%), the Brazilian Biodiversity Institute and National Parks Authority affiliated to the Ministry of the Environment (including the Brazilian Important Bird Area programme; De Luca et al., 2009); (b) WikiAves (59\%), a Brazilian citizen science records database; (c) eBird (33\%), an online database of bird observation records, mainly contributed by amateur birdwatchers (Sullivan et al., 2014); and (d) museum specimen data and literature-based records (3\%), including Collar et al. (1992), Dornas et al. (2013), Moreira Rios et al. (2020) 
and VertNet (Constable et al., 2010). Given the difficulty of extracting exact coordinates from WikiAves (records are assigned to municipal centroids by default), we manually extracted exact coordinates only where these represented the only known records within a municipality. We further checked all occurrence records and discarded twelve, indicated by the observers as likely to involve escaped or released confiscated individuals or else flagged as potential identification errors, where no physical evidence was provided. Given that a single location is assigned to each eBird checklist irrespective of the length or duration of the birdwatching trip, we also filtered eBird records to include only those with a transect length $<10 \mathrm{~km}$ or duration $<6 \mathrm{hr}$. To reduce sampling bias, exact spatial duplicates were removed from both datasets and thinned as described below (Fourcade et al., 2014). We also used eBird checklists ( $n=27,148$ ) from the study area that lacked observations of Hyacinth Macaws in order to validate our presence records and to inform our search for areas that might hold unknown populations of the species. We only used checklists marked "complete," that is, where birders confirmed that all known species had been recorded on the trip. These "eBird absences" were distributed across many of the gaps among the Hyacinth Macaw presence points post-2010 (Figure 1a), providing some confidence that we have a relatively complete set of points for the current habitat model.

Given the date range of the predictors (see below), we only used occurrence records from 1995 to 2019, therefore removing all undated records (Table S1b). We also removed any record within $500 \mathrm{~m}$ of an urban centre or a delimited urban boundary (as potentially representing records in flight or erroneous locations), using the Brazilian government's official spatial data (IBGE, 2019). However, we acknowledge that a few genuine urban records may have been eliminated by this measure.

\subsection{2 | Predictors used in the model}

All but one of our predictors are based on mapBiomas, a highresolution, annual, classified land cover map for Brazil, produced from Landsat images at a 30 m resolution from 1985 to 2019, accessed via Google Earth Engine map (Map Biomas Project, 2019). We combined classes of cover/use into forest, natural non-forest (mainly Cerrado savanna habitat), wetlands, pasture (including pasture mosaic) and agriculture (including temporary and permanent crops) for each year. To understand how different temporal and spatial scales of land cover and land cover change influence the Hyacinth Macaw's distribution, we calculated the proportion of each combined land cover class within 10 and $30 \mathrm{~km}$ windows for each year and as the difference in proportion of each cover class at 10 -year intervals, approximately one generation length of the macaw (10.3 years; BirdLife International, 2019). Therefore, we constructed 20 predictors (five cover classes, two spatial scales, two time periods) for each

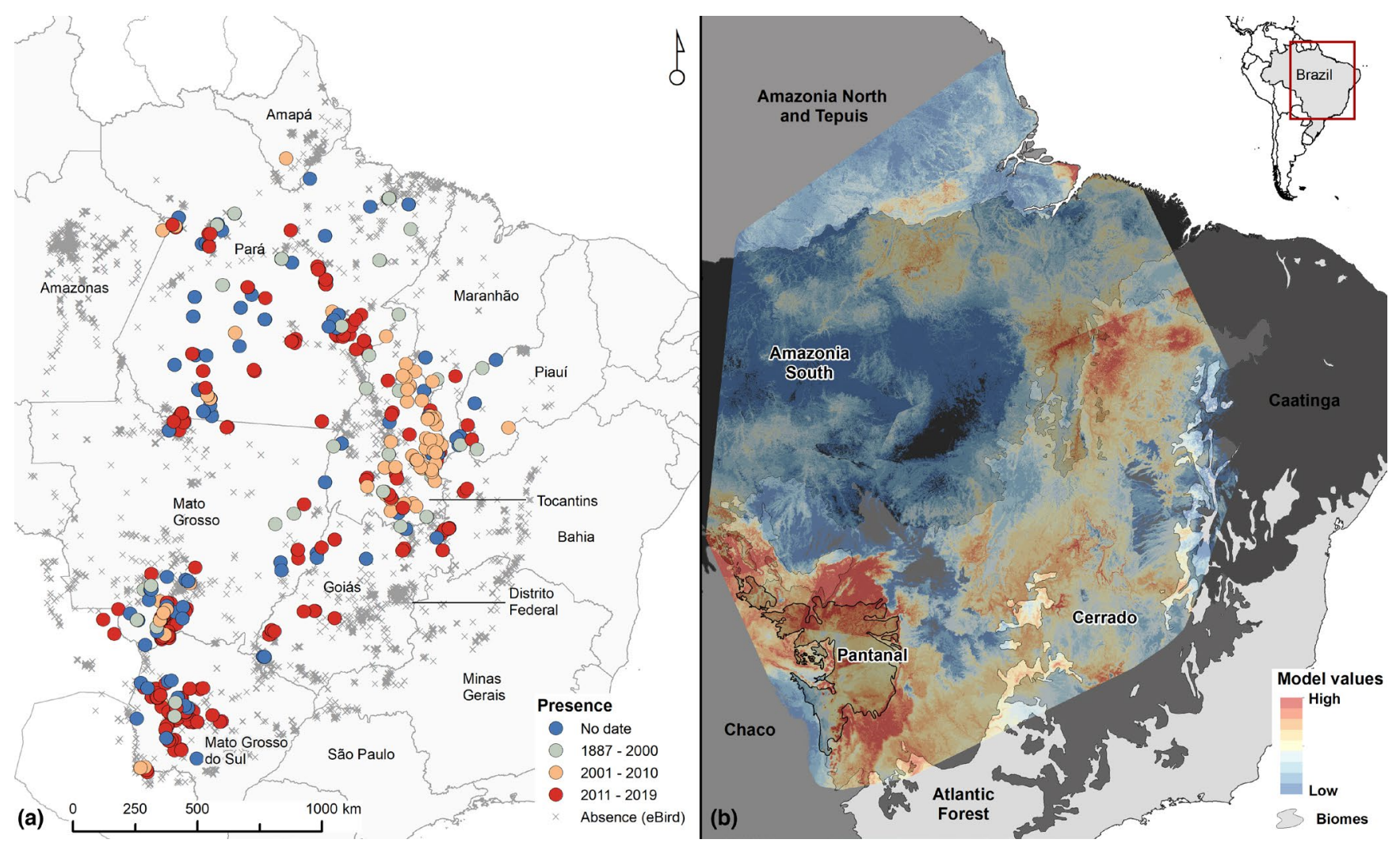

FIGURE 1 (a) Study area showing all occurrence points of Hyacinth Macaw Anodorhynchus hyacinthinus, grouped by year of record, and eBird absences; (b) modelled distributions of seven palms and one tree of importance for diet and nesting, respectively, summed and overlaid with biomes; used as a predictor in macaw distribution models 
year between 1995 and 2019, accounting for a 10-year lag since the start of mapBiomas data in 1985 (Figure S1). Data were exported from Google Earth Engine at $1 \mathrm{~km}$ resolution. Aware that the macaw is specialized on the fruits of several palms, for example Acrocomia and Attalea spp. (summarized in Collar et al., 1992; see also Tella et al., 2020), we also included a combined palm/tree occurrence predictor layer, consisting of the summed habitat suitability values from eight separate species distribution models for seven palms (Acrocomia aculeata, Acrocomia totai, Attalea eichleri, Attalea maripa, Attalea phalerata, Attalea speciosa and Syagrus coronata) as well as one tree species (Sterculia apetala) known to be important for food and nesting, respectively (Collar et al., 1992; Johnson et al., 1997; Pinho \& Nogueira, 2003; Pizo et al., 2008; Yamashita, 1997).

We combined 3,804 (median $=456$ ) occurrence records (Table S2 in supporting information) from the Botanical Information and Ecology Network (BIEN; Maitner et al., 2018), Global Biodiversity Information Facility (GBIF) and Balselv et al. (2019), and modelled distributions in Maxent using the same methods outlined below (see also Appendix S1), with climate variables from WorldClim v2.0 (Fick \& Hijmans, 2017) and elevation and slope calculated from a digital elevation model (Jarvis et al., 2008) at $1 \mathrm{~km}$ resolution (Table S2). The raw habitat suitability values from all models (all averaged AUC results were $>0.75$ ) were set to 0 below a 10 -percentile presence threshold and then summed to create a combined palm/tree presence layer (Figure 1b).

\subsection{3 | Modelling methods}

We set the modelling area to a convex hull around all the occurrence points and the BirdLife International range map (BirdLife International, 2019), with an additional buffer of $50 \mathrm{~km}$. This area was used to train models and predict geographic range extent and is slightly larger than that encompassing all known occurrence records. Given that there were too few occurrence records to train annual models-occurrence records are skewed towards more recent years, with only three years prior to 2015 having $>10$ records (Table S1b)-we trained a single model on data from all years, with predictor values selected from the year corresponding to the year of the record (Milanesi et al., 2020). This assumes that the relationship between distribution and the predictors has not changed over time, but we consider this reasonable in the space of 25 years. We thinned records to a distance of $5 \mathrm{~km}$, a distance which lessened bias due to records being clumped in areas of higher sighting activity while also maintaining sufficient records for modelling. Where multiple records existed at the same location for multiple years, we attempted to maintain the same distribution of records across the years as in the original dataset, resulting in a final set of 225 occurrence records (Table S1a, S1b). For the background data, we randomly sampled 10 sets of 10,000 pseudoabsences over the modelling area (BarbetMassin et al., 2012), across all years of the predictors.

We built models using Maxent, an often-used method (Merow et al., 2013; Phillips \& Dudík, 2008), with a record of high performance for species distribution models (Elith et al., 2006; Wisz et al., 2008). We tuned the model with eight different combinations of features consisting of linear, product, quadratic, hinge and threshold transformations of the predictors (Appendix S1), across seven values of the regularization parameter ( 0.5 to 3.5 , in steps of 0.5 ) using maxnet package in $R$ (Phillips et al., 2017) for each of the 10 pseudoabsence datasets. We evaluated model performance with fourfold spatial cross-validation using a double checkerboard pattern at two spatial scales to prevent spatial autocorrelation inflating evaluation metrics (Roberts et al., 2017). This approach, as implemented in the ENMeval package (Muscarella et al., 2014), spatially separates testing and training data. We present averaged AUC, Tjur $R^{2}$ (Tjur, 2009) biserial correlation and Boyce index (Di Cola et al., 2017) scores across the folds for each pseudoabsence run. The best model was chosen on highest AUC value and ties at three significant figures were broken with values of Tjur's $R^{2}$. Modelling scripts are available as supplementary files for Google Earth Engine and R (Appendix S1, in supplementary information). $\mathrm{R}$ code relied on the following packages, in addition to those stated above: dismo (Hijmans et al., 2020), raster (Hijmans, 2020) and sf (Pebesma, 2018). The best model for each pseudoabsence dataset was projected onto the time series of land cover predictors, from 1995 to 2019, and averaged to create a single annual prediction of macaw distribution. To constrain predictions to within suitable dispersion distances to occurrence points, we multiplied the averaged model with a distance-based penalty raster, with values assigned between 0 and 1 from a Gaussian decay function with a standard deviation of $250 \mathrm{~km}$ based on distance to nearest occurrence record, following similar methods in Thornhill et al. (2017). To create annual binary presence-absence maps, we applied a 10 -percentile presence value threshold on the averaged model outputs (Galante et al., 2018), corresponding to the maximum threshold value of all years with more than 10 presence points. This single threshold produces a conservative range, approximating more to the actual occupied area, while also overcoming the difficulty of selecting a year-specific threshold without sufficient presence points.

\subsection{Land cover changes within the range}

We used variable importance to indicate key potential drivers of distribution, as assessed by the variable permutation importance from the Maxent Java implementation (Phillips \& Dudík, 2008). Finally, we used partial response curves to determine the direction of the most influential variables. For each year, we quantified the change in range size within the Pantanal, Cerrado and Amazonia biomes using biome delimitations provided with mapBiomas (mapBiomas Project, 2019).

\section{3 | Priority search areas and protected area coverage}

We estimated the proportion of the most recent modelled range which is covered by protected areas (UNEP-WCMC \& IUCN, 2019). 
We calculated coverage of protected areas in IUCN categories I-IV (representing strongest protection on paper), categories V-VI (including sustainable use) and indigenous reserves. Where Brazilian protected area designations did not report IUCN categories, they were matched according to Bernard et al. (2014). We also calculated the amount and timing of, and reasons for, protected area degazettement from 1900 to 2014 within the Hyacinth Macaw's range, using spatial data published in Pack et al. (2016). Finally, we identified broad areas to search for undocumented populations of Hyacinth Macaw. From the thresholded modelled area corresponding to the latest year (2019), that is, highly suitable habitat for the macaw, we excluded areas within a $50 \mathrm{~km}$ radius around both eBird absences and positive macaw sightings within the last two decades in order to direct searches where no evidence exists for macaw presence or absence. This radius represents a feasible distance travelled by groups of similar macaw species within a day (Scherer-Neto et al., 2019). Therefore, these broad areas represent regions apparently unvisited by birdwatchers, without recent recorded presences of Hyacinth Macaw (although some have old records), but within suitable habitat as predicted by the model.

\section{3 | RESULTS}

\section{1 | Modelled range maps}

The best-tuned single, multi-annual models performed well across all ten pseudoabsence data runs, with metrics averaged across all runs and folds scoring $0.80( \pm 0.03 S D)$ for test AUC, $0.2( \pm 0.02)$ for test biserial correlation, $0.33( \pm 0.02)$ for test Tjur $R^{2}$ and $0.9( \pm 0.06)$ for test Boyce Index (Figure S2, Table S3). Evaluation metrics generally decreased with increased regularization across all features except for Boyce index (Figure S2), while hinge features alone, or all features combined, performed best, although results within the top five tuning runs were generally within three significant figures of each other (Table S3). All the predicted models across the 25-year series of land use data showed a clear separation between three main areas of high habitat suitability, approximately within each of the three biomes making up its habitat: Pantanal, Cerrado and Amazonia (Figure 2), with gaps in the Cerrado-Amazonia ecotonal region between the states of Pará and Mato Grosso and in the Cerrado-Pantanal ecotonal region.

\subsection{Decadal changes in habitat suitability and land cover within the range}

The predicted suitable habitat for the macaw expanded from $431,071 \mathrm{~km}^{2}$ in 1995 to $507,802 \mathrm{~km}^{2}$ in 2019 with different patterns of distributional change in each of the three biomes. In the Pantanal, the predicted area expanded southwards, in the Cerrado it showed increased fragmentation, whereas suitability in the Amazon expanded along rivers (Figure 2). Over this period, the total amount of suitable area in the Pantanal remained relatively stable, whereas suitable area increased steadily in the Amazon between 2000 and 2015 , equating to an increase of $81,220 \mathrm{~km}^{2}$ by 2019 . In the Cerrado suitable habitat decreased to a low in 2005, before closing in 2019 at $11,750 \mathrm{~km}^{2}$ less than in 1995 (Figure 3). In terms of land use over the last 30 years or three-generation lengths of the macaw, within the modelled area (in effect, the macaw's extent of occurrence), agriculture has expanded by over $225,000 \mathrm{~km}^{2}$ and pasture by $380,000 \mathrm{~km}^{2}$, while forest has declined by $400,000 \mathrm{~km}^{2}$ and savanna by $220,000 \mathrm{~km}^{2}$, with pasture and agriculture combined equating to over $30 \%$ of this area by 2019 . Fragmentation of forest and savanna
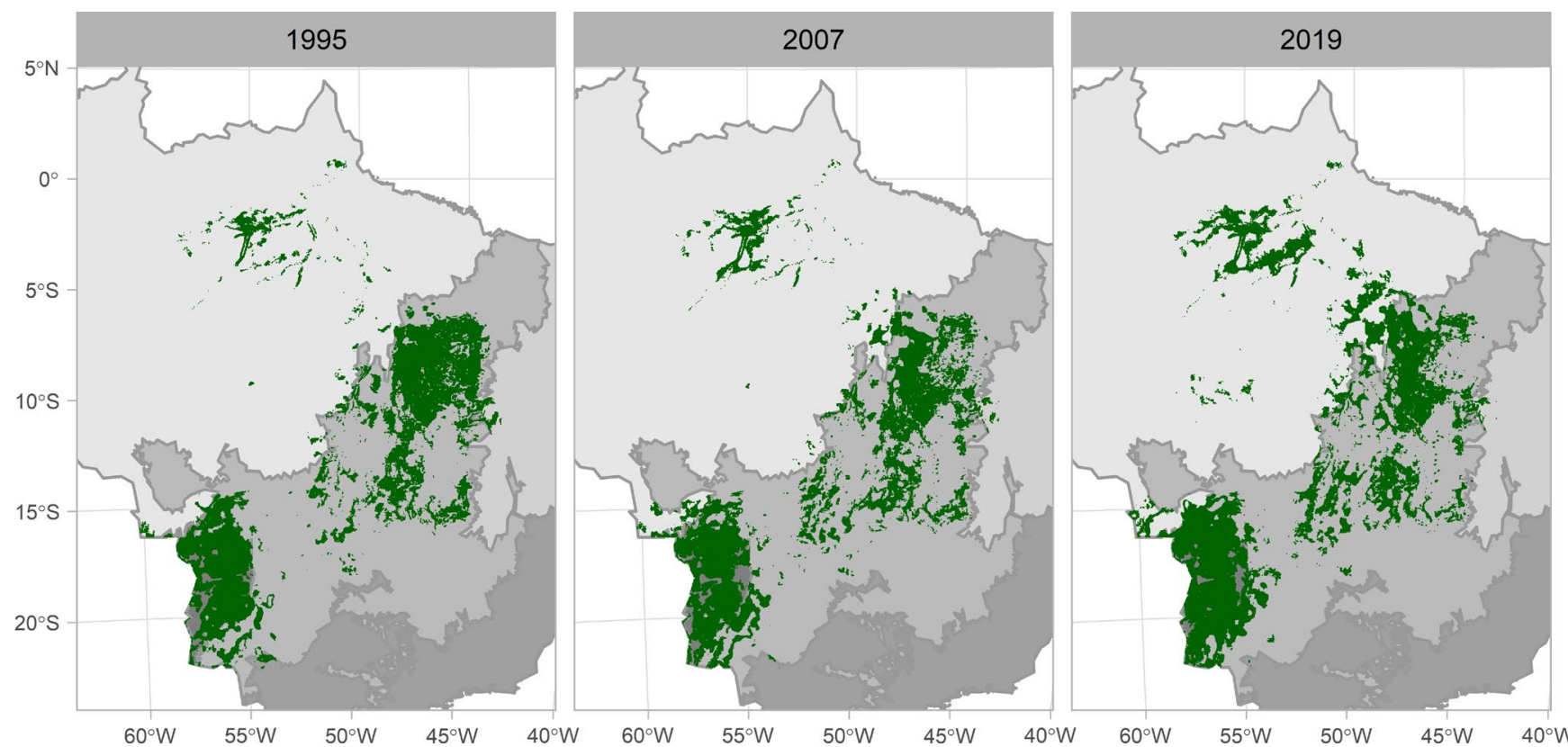

FIGURE 2 Modelled distributions of Hyacinth Macaw for 1995, 2007 and 2019, based on land cover models 
areas has increased strongly over this period (Figure S1a). Habitat change in the form of increasing pasture, with a corresponding decrease in forest, was most rapid from the early 1990s through to the early 2000s, markedly levelling off just before 2010, while agriculture increased more steadily throughout the period (Figure S3 in supporting information). The areas of most substantial habitat change concern conversion to pasture in the Amazon and the Cerrado bordering the Pantanal (Figure S1b).

\subsection{Likely drivers of habitat suitability and range change}

Three of the 21 predictors showed notably high importance values (Figure 4): presence of palms; presence of forest at the $10 \mathrm{~km}$ scale; and changes in pasture over 10 years. In general, the predictors at the wider landscape scale of $30 \mathrm{~km}$ were more important than those at the $10 \mathrm{~km}$ scale, as were predictors describing habitat types at

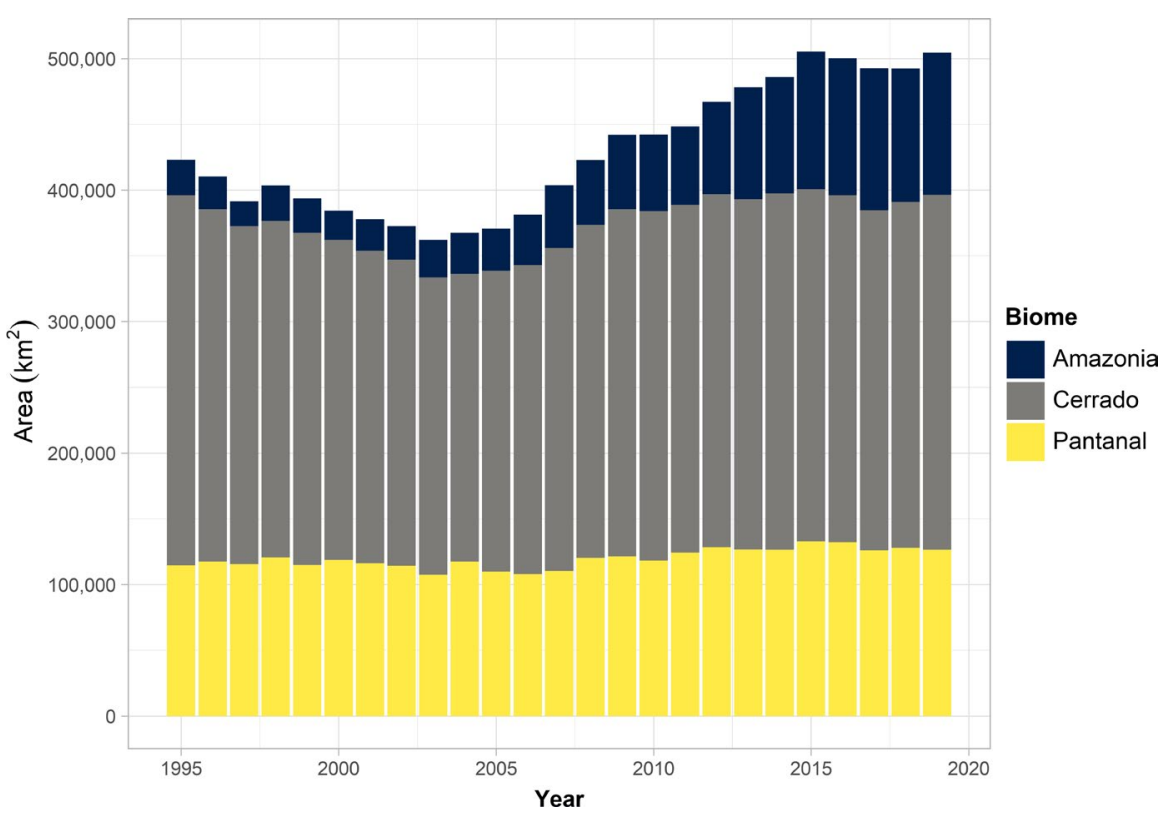

(a)

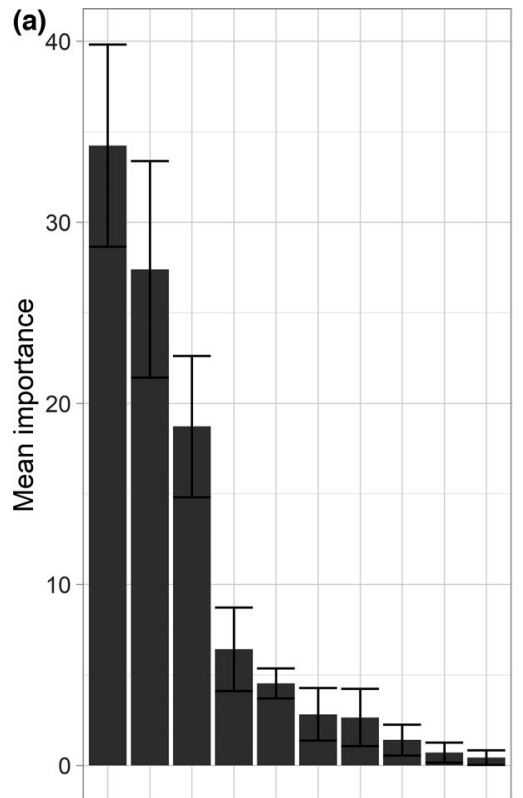

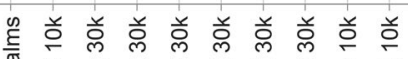

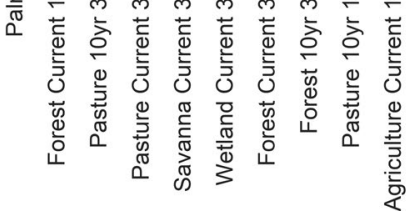

(b)
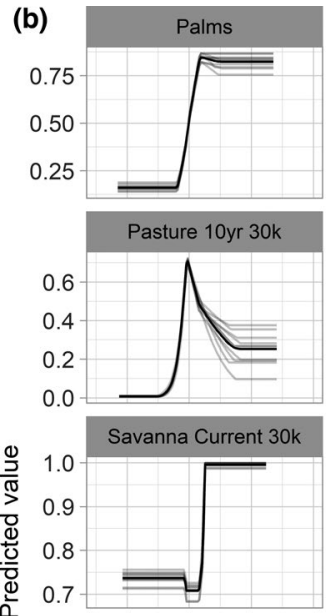

口.
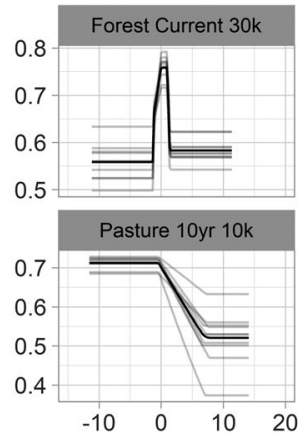

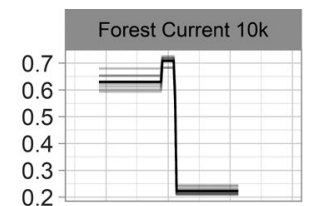

Pasture Current $30 \mathrm{k}$

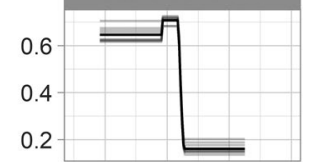

Wetland Current 30k
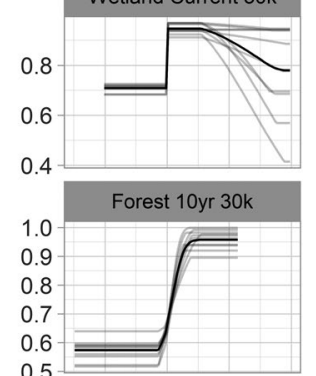

Agriculture Current $10 \mathrm{k}$

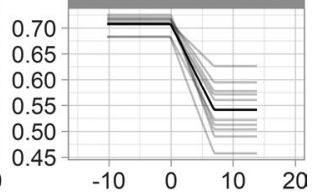

FIGURE 3 Change in suitable area of Hyacinth Macaw distribution 1995-2019 in the Pantanal, Cerrado and Amazonia biomes
FIGURE 4 (a) Mean variable importance ( \pm standard deviation) of the 10 most important variables across all pseudoabsence runs in the Hyacinth Macaw distribution model, and (b) corresponding response curves for each run, with mean response in bold 
the present time rather than those describing land cover changes over the previous decade. In terms of direction of responses, habitat suitability increased with increasing presence of palms, decreased with increasing forest presence at the smaller landscape scale after a period of stability and showed a unimodal response to change in proportion of pasture, with suitability decreasing with gain in pasture after reaching a peak (Figure 4). Response patterns were generally similar at both landscape scales in terms of direction.

\subsection{Priority areas and protected area coverage}

Over $310,000 \mathrm{~km}^{2}$ of protected areas $\left(117,000 \mathrm{~km}^{2}\right.$ in IUCN categories I-IV) overlap to some degree with the Hyacinth Macaw's predicted current (2019) distribution, but mostly at its periphery (Figure $5 \mathrm{a}$ ), so that only approximately $8 \%$ of the range is currently protected. Moreover, between 1971 and 2014, nine protected areas within this range, almost all within IUCN categories I-IV, lost more than $21,500 \mathrm{~km}^{2}$ owing to downsizing, downgrading or degazetting (Figure 5b, Table 1). Four degazettement events were due to land claims or rural settlements and four to industrial or hydropower infrastructure, with more than half occurring since 2000. A further six areas have active degazettement proposals, threatening a further $10,500 \mathrm{~km}^{2}$ (Table 1). Areas where undetected macaw populations may persist were broadly delimited in eight regions in the Brazilian states of Pará, Maranhão, Tocantins/Goiás and Mato Grosso/Mato Grosso do Sul (Figure 5d). These regions have suitable current land cover and climate but no recent observations of Hyacinth Macaws and have not been visited by birdwatchers using eBird. Areas with similar conditions, but with known absences from eBird, were highlighted as sites of possible local extinction (Figure $5 \mathrm{~d}$ ).

\section{4 | DISCUSSION}

Species such as the Hyacinth Macaw, with vast and hard-to-access ranges, are very difficult to study comprehensively, resulting in a scarcity of ecological metrics required for range-wide conservation planning. Our modelling approach combined multi-temporal occurrence records with year-specific land use/cover data to assess range change and potential drivers of distribution. There is a growing realization of the important role that land cover data plays within species distribution modelling (Chauvier et al., 2021; Kort et al., 2020), especially at different temporal and spatial scales as a proxy for key processes of ecosystem functioning controlling species distribution and abundance patterns (Arenas-Castro et al., 2019). However, incorporating time series of land cover data has followed different approaches, for example, by calculating seasonal variation in land cover (or vegetation indices) at occurrence points (e.g. annual variation; Devenish et al., 2020; Radeloff et al., 2019), constructing multiple models at multiple points over a time series (Carone et al., 2014; Gschweng et al., 2012) or similarly to our approach, by pooling multi-temporal species locations with year-specific predictor data
(Li et al., 2017; Milanesi et al., 2020). Whereas the former methods rely on sufficient observations for each time period to build successful models, the latter combines data into a single model, making it suitable for using land cover time series in models for rarer species. Our approach is also adaptable to use with time series of remotesensed vegetation indices, available globally, rather than classified land cover.

Our results indicate a complex, changing distributional pattern of the Hyacinth Macaw in response to changing land cover over its range, with marked differences across the three biomes it inhabits. While the extent of its range remained relatively stable between 1995 and 2019 in the Cerrado and Pantanal biomes, it increased in the Amazon, possibly due to an opening up of the habitat, especially along rivers. However, as borne out by the negative response curves for pasture and agriculture, this benefit would eventually be lost when these land cover classes go beyond a tipping point with regard to the proportion of natural habitat. A recent gain in range may represent a future debt in population loss if large-scale conversion of natural habitats to monocultural farming in the Cerrado and Amazon continues (Lahsen et al., 2016; Lovejoy \& Nobre, 2019). It is plausible to assume that ongoing agricultural expansion (Figure $5 \mathrm{c}$ ), especially in the "MAPITOBA" region (the broad area where the states of Maranhão, Piauí, Tocantins and Bahia meet; Rodriguez et al., 2018), has also changed habitat structural properties of importance to the macaw (Espírito-Santo et al., 2016), such as presence of palm stands and gallery forests within savannas. Small-scale subsistence agricultural regimes may be less damaging in this respect. Nevertheless, a confounding factor in the macaw's relationship with agriculture is its possible reliance on megafauna-adapted seeds, and the role played by modern cattle in facilitating this relationship through seed-regurgitation (Tella et al., 2020; Yamashita, 1997). Certainly, the known importance of palm stands to the species should not be underestimated (Yamashita \& Valle, 1993). The macaw's relationship with palm distribution is clear from our results, and although each biome hosts several species of palm utilized by the species (Guedes, 2004; Yamashita, 1997), the highest values of habitat suitability in the Pantanal interestingly coincide with the highest richness of the modelled palm species.

A lack of occurrence records and suitable habitat implies the species is now regionally extinct in north-east Brazil in the "Belem Area of Endemism" (Lees et al., 2012; Sclater \& Salvin, 1867), south-east Amapá, and southern Maranhão/northern Piauí, with the nearest populations up to $500 \mathrm{~km}$ away. These areas have a longer history of human occupation, which presumably would have facilitated the exploitation of these populations for the international wildlife trade. Such pressure appears to have abated in this century but nevertheless persists, involving at least the Pantanal and Cerrado populations (Presti et al., 2015), while little appears to be known about the continuing use of macaw feathers by indigenous communities in these regions. Further, there is evidence of the species' range-wide scarcity, possibly linked to these local extinctions, from the lack of records at well-visited birdwatching sites $<100 \mathrm{~km}$ from places with positive sightings (Lees et al., 2013; Whittaker, 2009). This may also 


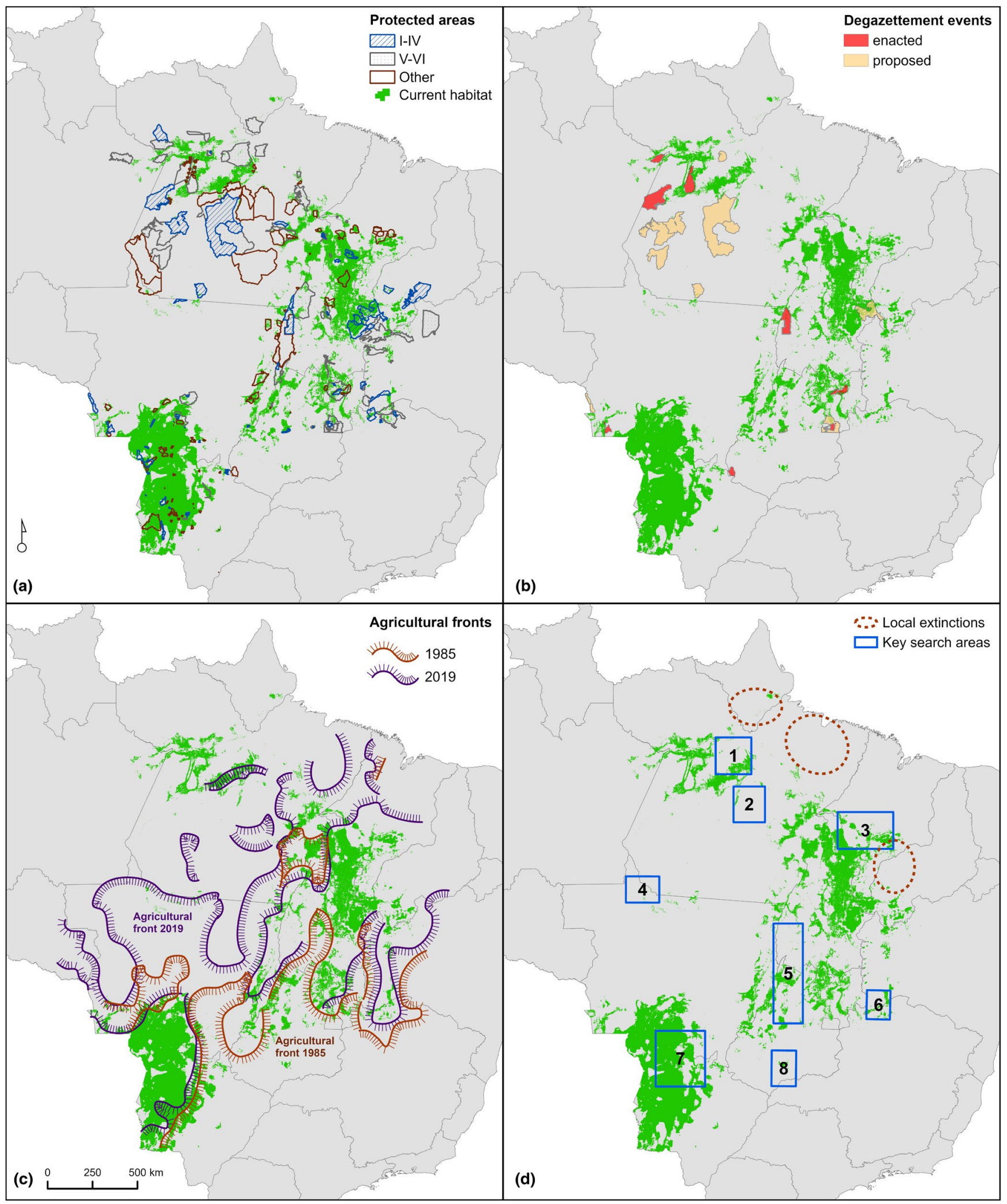

FIGURE 5 (a) Protected areas overlapping with the Hyacinth Macaw's predicted current range (for 2019). Protected areas are shown by IUCN categories; most of those in the category "Other" are indigenous reserves; (b) enacted and proposed degazettement events within protected areas, 1971 to 2014. (c) Expansion of agricultural fronts within the range between 1985 and 2019; (d) key areas for searches (numbered boxes) and local extinctions. Search areas: 1-central Pará north of the Transamazonica Highway; 2-the Iriri-Xingu interfluvial region in Pará; 3-southern Maranhão; 4-the extreme north of Mato Grosso; 5-the Araguaia region of southern Tocantins and north Goiás; 6-northern Minas Gerais/south-western Bahia; 7-the eastern Pantanal in Mato Grosso/Mato Grosso do Sul, 8-south-east Goiás 
TABLE 1 Area lost or under active proposal to be degazetted from protected areas between 1971 and 2014 within the Hyacinth Macaw's current range

\begin{tabular}{lllll} 
Status & IUCN category & $\begin{array}{l}\text { Number of PAs } \\
\text { affected }\end{array}$ & $\begin{array}{l}\text { Area lost } \\
\left(\mathbf{k m}^{2}\right)\end{array}$ & Year range \\
\hline Enacted & I-IV & 6 & 21,252 & $1971-2014$ \\
& V-VI & 3 & 378 & $1996-2012$ \\
& All categories & 9 & 21,630 & $1971-2014$ \\
\hline Under active proposal & I-IV & 4 & 5,475 & $2006-2014$ \\
& V-VI & 2 & 4,977 & $2007-2013$ \\
& All categories & 6 & 10,452 & $2006-2014$ \\
\hline
\end{tabular}

be indicative of its wide-ranging habits in seeking food resources over large areas. Our model results also indicate the importance of wider-scale landscape predictors, likely to be in accordance with daily or seasonal population movements (Scherer-Neto et al., 2019). In fact, seasonal movements may be behind some occurrence points apparently outside areas of suitable habitat (e.g. in southern Pará), with migratory movements in the species long since hinted at (Collar et al., 1992) and recent genetic links found between distant populations (Faria et al., 2008). More research on distribution is required in these areas. However, notwithstanding its scarcity, given the extent of current occurrence records and the modelled extent of suitable habitat, the global population estimate of 6,500 (de Almeida et al., 2019; Tella et al., 2020), with 5,000 in the Pantanal, 1,000 in the Cerrado and 500 in the Amazon (Faria et al., 2008), is clearly in need of upward revision, again, requiring field surveys.

There is little congruence between protected area coverage and the range of the Hyacinth Macaw, with most conservation areas situated at its range margins. The benefits of protected areas will be further reduced if proposed degazettement of parks overlapping its range are implemented (Mascia et al., 2014; Pack et al., 2016). Degazettement is especially worrying given that most has involved stricter conservation areas (IUCN categories I-IV), where deforestation rates have been significantly less than in sustainable-use areas (Françoso et al., 2015). Such changes are also detrimental to large, globally threatened mammals, such as giant anteater Myrmecophaga tridactyla and lowland tapir Tapirus terrestris, recently shown to benefit from stricter levels of protection (Ferreira et al., 2020). Nevertheless, given the vast range of the macaw, strategies beyond protected areas are also vitally important, such as allowing vegetation regrowth after land abandonment and low-impact cattleranching (Espírito-Santo et al., 2016). To implement a range-wide conservation strategy, gaps in our knowledge of its distribution still need to be filled. We identify eight general areas throughout its range which our model predicts as potentially harbouring undetected populations. Searches within and beyond these areas will not, however, be straightforward, given the size and remoteness of the landscapes to be covered. A clear potential role therefore exists for citizen science, especially involving indigenous groups and protected area staff (Danielsen et al., 2000). Filling gaps in field data from such surveys, combined with ever-increasing information on changing land cover to evaluate range occupancy and habitat relationships, will help develop robust strategies for the long-term management of the Hyacinth Macaw.

Although our approach offers a clear advantage in that fewer records per year are needed, and is therefore particularly suited for poorly known species, it comes with a caveat in that multi-temporal models assume that a species' response to habitat and habitat change is consistent across years. This may not necessarily be the case if there is an overriding landscape context to a species' habitat associations (very large-ranged or nomadic species; Andrew \& Fox, 2020); where exploitation or disease influence changes over time (Faurby \& Araújo, 2018); or when demographic changes or biotic interactions are not accounted for (Zurell, 2017). However, for elusive, poorly studied or conservation-dependent species, typically lacking data, our method may have wide applicability to track changes in area of occupancy or extent of occurrence across years, in support of extinction risk assessments and global biodiversity targets (Brooks et al., 2015). Further, in setting conservation priorities, tracking such changes over time may be useful in selecting areas with longer histories of species persistence (Vellend \& Kharouba, 2013) or translating trends in habitat suitability to changes in population size or abundance (Devenish, 2017; Weber et al., 2017). In terms of assessing extinction risk for the macaw, although we have no data on population size or trends, our results suggest a significant potential increase in the area of occupancy of the species. Whether this correlates with an increase in population is not known but it seems likely that land use change, especially in the Amazon, perhaps coupled with the beneficial effects of cessation of widespread trapping in the last 2-3 decades (ICMBio, 2018), may have allowed populations to increase as well as expand. In conclusion, these models may be useful in a range of situations and while they can still be improved by obtaining new data on threatened and poorly known species-enabling separate models for each period and allowing the response of the species to vary accordingly (Zuckerberg et al., 2016) - with limited data from the past, they represent an informative method to evaluate historic trajectories of range change.

\section{ACKNOWLEDGEMENTS}

We are very grateful to Priscilla Prudente do Amaral for providing the ICMBio data, Robert Muscarella for his advice on palm distributions, Shalynn M. Pack for providing degazettement shapefiles, Fernando Favaro for confirmation of records at Terra do Meio, 
and all those who contributed to species occurrence records at WikiAves, eBird, VertNet and other databases. We thank the Parrot Wild Life Foundation (PWLF) which, through the kindness of Eric Vignot, funded this study, and we also thank Jonas Livet for help facilitating the work.

\section{CONFLICTS OF INTEREST}

The authors declare no conflicts of interest.

\section{PEER REVIEW}

The peer review history for this article is available at https://publo ns.com/publon/10.1111/ddi.13395.

\section{DATA AVAILABILITY STATEMENT}

Species occurrence points are available in supplementary information. All other data are available online. Model predictors-Climate data: https://worldclim.com/; Google Earth Engine Catalogues: mapBiomas: projects/mapbiomas-workspace/public/collection3_1/ mapbiomas_collection31_integration_v1; Digital Elevation Model: CGIAR/SRTM90_V4.

Scripts are available at: https://github.com/Cdevenish/A_hyaci nthinus_project.

\section{ORCID}

Christian Devenish iD https://orcid.org/0000-0002-5249-0844

Alexander C. Lees iD https://orcid.org/0000-0001-7603-9081

\section{REFERENCES}

Amiri, M., Tarkesh, M., Jafari, R., \& Jetschke, G. (2020). Bioclimatic variables from precipitation and temperature records vs. remote sensing-based bioclimatic variables: Which side can perform better in species distribution modeling? Ecological Informatics, 57, 101060. https://doi.org/10.1016/j.ecoinf.2020.101060

Andrew, M. E., \& Fox, E. (2020). Modelling species distributions in dynamic landscapes: The importance of the temporal dimension. Journal of Biogeography, 47(7), 1510-1529. https://doi.org/10.1111/jbi.13832

Arenas-Castro, S., Regos, A., Gonçalves, J. F., Alcaraz-Segura, D., \& Honrado, J. (2019). Remotely sensed variables of ecosystem functioning support robust predictions of abundance patterns for rare species. Remote Sensing, 11(18), 2086. https://doi.org/10.3390/rs111 82086

Balslev, H., Kristiansen, S. M., \& Muscarella, R. (2019). Palm community transects and soil properties in western Amazonia. Ecology, 100(12), e02841. https://doi.org/10.1002/ecy.2841

Barbet-Massin, M., Jiguet, F., Albert, C. H., \& Thuiller, W. (2012). Selecting pseudo-absences for species distribution models: How, where and how many? Methods in Ecology and Evolution, 3(2), 327-338. https:// doi.org/10.1111/j.2041-210X.2011.00172.x

Bernard, E., Penna, L. A. O., \& Araújo, E. (2014). Downgrading, downsizing, degazettement, and reclassification of protected areas in Brazil. Conservation Biology, 28(4), 939-950. https://doi.org/10.1111/ cobi.12298

BirdLife International (2019). IUCN Red List for birds-Species factsheet: Anodorhynchus hyacinthinus. Retrieved from http://datazone.birdlife. org/species/factsheet/hyacinth-macaw-anodorhynchus-hyacinthin us/text

Bradley, B. A., \& Fleishman, E. (2008). Can remote sensing of land cover improve species distribution modelling? Journal of Biogeography, 35(7), 1158-1159. https://doi.org/10.1111/j.1365-2699.2008.01928.x
Breiner, F. T., Guisan, A., Nobis, M. P., \& Bergamini, A. (2017). Including environmental niche information to improve IUCN Red List assessments. Diversity and Distributions, 23(5), 484-495. https://doi. org/10.1111/ddi.12545

Brooks, T. M., Butchart, S. H. M., Cox, N. A., Heath, M., Hilton-Taylor, C., Hoffmann, M., Kingston, N., Rodríguez, J. P., Stuart, S. N., \& Smart, J. (2015). Harnessing biodiversity and conservation knowledge products to track the Aichi Targets and Sustainable Development Goals. Biodiversity, 16(2-3), 157-174. https://doi.org/10.1080/14888 386.2015.1075903

Carone, M. T., Guisan, A., Cianfrani, C., Simoniello, T., Loy, A., \& Carranza, M. L. (2014). A multi-temporal approach to model endangered species distribution in Europe. The case of the Eurasian otter in Italy. Ecological Modelling, 274, 21-28. https://doi.org/10.1016/j.ecolm odel.2013.11.027

Chauvier, Y., Thuiller, W., Brun, P., Lavergne, S., Descombes, P., Karger, D. N., Renaud, J., \& Zimmermann, N. E. (2021). Influence of climate, soil, and land cover on plant species distribution in the European Alps. Ecological Monographs, 91(2), e01433. https://doi.org/10.1002/ ecm.1433

Chen, J., Chen, J., Liao, A., Cao, X., Chen, L., Chen, X., He, C., Han, G., Peng, S., Lu, M., Zhang, W., Tong, X., \& Mills, J. (2015). Global land cover mapping at $30 \mathrm{~m}$ resolution: A POK-based operational approach. ISPRS Journal of Photogrammetry and Remote Sensing, 103, 7-27. https://doi.org/10.1016/j.isprsjprs.2014.09.002

Collar, N. J., Gonzaga, L. P., Krabbe, N., Madroño Nieto, A., Naranjo, L. G., Parker, T. A. III, \& Wege, D. C. (1992). Threatened birds of the Americas, 3rd ed. International Council for Bird Preservation.

Constable, H., Guralnick, R., Wieczorek, J., Spencer, C., Peterson, A. T., \& Committee, T. V. N. S. (2010). VertNet: A new model for biodiversity data sharing. PLoS Biology, 8(2), e1000309. https://doi.org/10.1371/ journal.pbio.1000309

Cord, A., \& Rödder, D. (2011). Inclusion of habitat availability in species distribution models through multi-temporal remote-sensing data? Ecological Applications, 21(8), 3285-3298. https://doi. org/10.1890/11-0114.1

da Silva, G. F., Presti, F. T., Rechetelo, J., Guedes, N. M. R., Wasko, A. P., \& Donatelli, R. J. (2019). Hyacinth Macaw (Anodorhynchus hyacinthinus) nests in a mosaic of protected areas in Carajás and surrounding areas, state of Pará, Brazil. Revista Brasileira de Ornitologia, 27(3), 187194. https://doi.org/10.1007/BF03544469

Danielsen, F., Balete, D. S., Poulsen, M. K., Enghoff, M., Nozawa, C. M., \& Jensen, A. E. (2000). A simple system for monitoring biodiversity in protected areas of a developing country. Biodiversity \& Conservation, 9(12), 1671-1705. https://doi.org/10.1023/A:1026505324342

de Almeida, T. R. A., Presti, F. T., Cruz, V. P., \& Wasko, A. P. (2019). Genetic analysis of the endangered Hyacinth Macaw (Anodorhynchus hyacinthinus) based on mitochondrial markers: Different conservation efforts are required for different populations. Journal of Ornithology, 160(3), 711-720. https://doi.org/10.1007/s10336-019-01652-z

De Luca, A. C., Develey, P. F., Bencke, G. A., \& Goerck, J. M. (2009). Áreas importantes para a conservação das aves no Brasil-Parte II Amazonia, Cerrado e Pantanal. SAVE Brasil.

Devenish, C. (2017). Developing tools for improved population and range estimation in support of extinction risk assessments for Neotropical birds. $\mathrm{PhD}$ Thesis, Manchester Metropolitan University. https://e-space. mmu.ac.uk/618193/

Devenish, C., Cortez, E. N., Buchanan, G., Smith, G. R., \& Marsden, S. J. (2020). Estimating ecological metrics for holistic conservation management in a biodiverse but information-poor tropical region. Conservation Science and Practice, 2(2), e153. https://doi. org/10.1111/csp2.153

Di Cola, V., Broennimann, O., Petitpierre, B., Breiner, F. T., D'Amen, M., Randin, C., Engler, R., Pottier, J., Pio, D., Dubuis, A., Pellissier, L., Mateo, R. G., Hordijk, W., Salamin, N., \& Guisan, A. (2017). ecospat: An $\mathrm{R}$ package to support spatial analyses and modeling of 
species niches and distributions. Ecography, 40, 774-787. https://doi. org/10.1111/ecog.02671

Dornas, T., Barbosa, M. O., Leite, G., Pinheiro, R. T., Prado, A. D., Crozariol, M. A., \& Carrano, E. (2013). Ocorrências da Arara-azul-grande (Anodorhynchus hyacinthinus) no Estado do Tocantins: Distribuição, implicações biogeográficas e conservação. Ornithologia, 6(1), 22-35.

Elith, J., Graham, C. H., Anderson, R. P., Dudík, M., Ferrier, S., Guisan, A., Hijmans, R. J., Huettmann, F., Leathwick, J. R., Lehmann, A., Li, J., Lohmann, L. G., Loiselle, B. A., Manion, G., Moritz, C., Nakamura, M., Nakazawa, Y., Overton, J. McC., Peterson, A. T., ... Zimmermann, N. E. (2006). Novel methods improve prediction of species' distributions from occurrence data. Ecography, 29(2), 129-151. https://doi. org/10.1111/j.2006.0906-7590.04596.x

Espírito-Santo, M. M., Leite, M. E., Silva, J. O., Barbosa, R. S., Rocha, A. M., Anaya, F. C., \& Dupin, M. G. V. (2016). Understanding patterns of land-cover change in the Brazilian Cerrado from 2000 to 2015. Philosophical Transactions of the Royal Society B: Biological Sciences, 371(1703), 20150435. https://doi.org/10.1098/rstb.2015.0435

Faria, P. J., Guedes, N. M. R., Yamashita, C., Martuscelli, P., \& Miyaki, C. Y. (2008). Genetic variation and population structure of the endangered Hyacinth Macaw (Anodorhynchus hyacinthinus): Implications for conservation. Biodiversity and Conservation, 17(4), 765-779. https://doi.org/10.1007/s10531-007-9312-1

Faurby, S., \& Araújo, M. B. (2018). Anthropogenic range contractions bias species climate change forecasts. Nature Climate Change, 8(3), 252256. https://doi.org/10.1038/s41558-018-0089-x

Ferreira, G. B., Collen, B., Newbold, T., Oliveira, M. J. R., Pinheiro, M. S., de Pinho, F. F., Rowcliffe, M., \& Carbone, C. (2020). Strict protected areas are essential for the conservation of larger and threatened mammals in a priority region of the Brazilian Cerrado. Biological Conservation, 251, 108762. https://doi.org/10.1016/j.biocon.2020.108762

Fick, S. E., \& Hijmans, R. J. (2017). WorldClim 2: New 1-km spatial resolution climate surfaces for global land areas. International Journal of Climatology, 37(12), 4302-4315. https://doi.org/10.1002/joc.5086

Fourcade, Y., Engler, J. O., Rödder, D., \& Secondi, J. (2014). Mapping species distributions with MAXENT using a geographically biased sample of presence data: A performance assessment of methods for correcting sampling bias. PLoS One, 9(5), e97122. https://doi. org/10.1371/journal.pone.0097122

Françoso, R. D., Brandão, R., Nogueira, C. C., Salmona, Y. B., Machado, R. B., \& Colli, G. R. (2015). Habitat loss and the effectiveness of protected areas in the Cerrado Biodiversity Hotspot. Natureza \& Conservação, 13(1), 35-40. https://doi.org/10.1016/j.ncon.2015.04.001

Galante, P. J., Alade, B., Muscarella, R., Jansa, S. A., Goodman, S. M., \& Anderson, R. P. (2018). The challenge of modeling niches and distributions for data-poor species: A comprehensive approach to model complexity. Ecography, 41(5), 726-736. https://doi.org/10.1111/ ecog.02909

Gschweng, M., Kalko, E. K. V., Berthold, P., Fiedler, W., \& Fahr, J. (2012). Multi-temporal distribution modelling with satellite tracking data: Predicting responses of a long-distance migrant to changing environmental conditions. Journal of Applied Ecology, 49(4), 803-813. https:// doi.org/10.1111/j.1365-2664.2012.02170.x

Guedes, N. M. R. (2004). Management and conservation of the large macaws in the wild. Ornitologia Neotropical, 15(Suppl), 279-283.

Hansen, M. C., Potapov, P. V., Moore, R., Hancher, M., Turubanova, S. A., Tyukavina, A., Thau, D., Stehman, S. V., Goetz, S. J., Loveland, T. R., Kommareddy, A., Egorov, A., Chini, L., Justice, C. O., \& Townshend, J. R. G. (2013). High-resolution global maps of 21st-century forest cover change. Science, 342(6160), 850-853. https://doi.org/10.1126/ science. 1244693

He, K. S., Bradley, B. A., Cord, A. F., Rocchini, D., Tuanmu, M.-N., Schmidtlein, S., Turner, W., Wegmann, M., \& Pettorelli, N. (2015). Will remote sensing shape the next generation of species distribution models? Remote Sensing in Ecology and Conservation, 1(1), 4-18. https://doi.org/10.1002/rse2.7
Hijmans, R. J. (2020). Raster: Geographic data analysis and modeling. (3.012) $[R]$. Retrieved from http://CRAN.R-project.org/package $=$ raster

Hijmans, R. J., Phillips, S., Leathwick, J., \& Elith, J. (2020). Dismo: Species Distribution Modeling. R package (1.1-4) [Computer software]. Retrieved from http://CRAN.R-project.org/package=dismo

Hoffmann, M., Hilton-Taylor, C., Angulo, A., Böhm, M., Brooks, T. M., Butchart, S. H. M., Carpenter, K. E., Chanson, J., Collen, B., Cox, N. A., Darwall, W. R. T., Dulvy, N. K., Harrison, L. R., Katariya, V., Pollock, C. M., Quader, S., Richman, N. I., Rodrigues, A. S. L., Tognelli, M. F., ... Stuart, S. N. (2010). The impact of conservation on the status of the world's vertebrates. Science, 330(6010), 1503-1509. https://doi. org/10.1126/science.1194442

IBGE (2019). Base Cartográfica Contínua do Brasil, escala 1:250.000 BC250 (versão 2019) [Map]. IBGE - Instituto Brasileiro de Geografia e Estatística.

ICMBio. (2018). Livro Vermelho da Fauna Brasileira Ameaçada de Extinção: Volume III - Aves (Vol. 3). ICMBio - Instituto Chico Mendes de Conservação da Biodiversidade.

IUCN. (2016). Guidelines for Using the IUCN Red List Categories and Criteria. Version 12.0. IUCN Standards and Petitions Working Group. Retrieved from http://www.iucnredlist.org/documents/RedListGui delines.pdf

Jarvis, A., Reuter, H. A., Nelson, A., \& Guevara, E. (2008). Hole-filled seamless SRTM data V4 [Map]. International Centre for Tropical Agriculture. Retrieved from http://srtm.csi.cgiar.org

Johnson, M. A., Moraes Tomas, W., \& Robaldo Guedes, N. M. (1997). On the hyacinth macaw's nesting tree: Density of young manduvis around adult trees under three different management conditions in the Pantanal wetland. Ararajuba, 5, 185-188.

Kort, H. D., Baguette, M., Lenoir, J., \& Stevens, V. M. (2020). Toward reliable habitat suitability and accessibility models in an era of multiple environmental stressors. Ecology and Evolution, 10(20), 1093710952. https://doi.org/10.1002/ece3.6753

Lahsen, M., Bustamante, M. M. C., \& Dalla-Nora, E. L. (2016). Undervaluing and overexploiting the Brazilian Cerrado at our peril. Environment: Science and Policy for Sustainable Development, 58(6), 415. https://doi.org/10.1080/00139157.2016.1229537

Lang, S., Mairota, P., Pernkopf, L., \& Schioppa, E. P. (2015). Earth observation for habitat mapping and biodiversity monitoring. International Journal of Applied Earth Observation and Geoinformation, 37, 1-6. https://doi.org/10.1016/j.jag.2014.10.007

Lees, A. C., de Moura, N. G., Santana, A., Aleixo, A., Barlow, J., Berenguer, E., Ferreira, J., \& Gardner, T. A. (2012). Paragominas: A quantitative baseline inventory of an eastern Amazonian avifauna. Revista Brasileira de Ornitologia, 20, 93-118.

Lees, A. C., Zimmer, K. J., Marantz, C. A., Whittaker, A., Davis, B. J. W., \& Whitney, B. M. (2013). Alta Floresta revisited: An updated review of the avifauna of the most intensively surveyed locality in southcentral Amazonia. Bulletin of the British Ornithologists' Club, 133(3), 178-239.

Li, X., Si, Y., Ji, L., \& Gong, P. (2017). Dynamic response of East Asian Greater White-fronted Geese to changes of environment during migration: Use of multi-temporal species distribution model. Ecological Modelling, 360, 70-79. https://doi.org/10.1016/j.ecolm odel.2017.06.004

Lovejoy, T. E., \& Nobre, C. (2019). Amazon tipping point: Last chance for action. Science Advances, 5(12), eaba2949. https://doi.org/10.1126/ sciadv.aba2949

Machado, A. B. M., Drummond, G. M., \& Paglia, A. P. (Eds.). (2008). Livro Vermelho da Fauna Brasileira Ameaçada de Extinção-Vol II. Ministério do Meio Ambiente.

Maitner, B. S., Boyle, B., Casler, N., Condit, R., Donoghue, J., Durán, S. M., Guaderrama, D., Hinchliff, C. E., Jørgensen, P. M., Kraft, N. J. B., McGill, B., Merow, C., Morueta-Holme, N., Peet, R. K., Sandel, B., Schildhauer, M., Smith, S. A., Svenning, J.-C., Thiers, B., ... Enquist, B. J. (2018). The bien r package: A tool to access the Botanical Information 
and Ecology Network (BIEN) database. Methods in Ecology and Evolution, 9(2), 373-379. https://doi.org/10.1111/2041-210X.12861

mapBiomas Project (2019). Project mapBiomas-Brazilian Land Cover \& Use Map Series (Collection 3.1) [Map]. mapBiomas Project. Received from https://mapbiomas.org

Mascia, M. B., Pailler, S., Krithivasan, R., Roshchanka, V., Burns, D., Mlotha, M. J., Murray, D. R., \& Peng, N. (2014). Protected area downgrading, downsizing, and degazettement (PADDD) in Africa, Asia, and Latin America and the Caribbean, 1900-2010. Biological Conservation, 169, 355-361. https://doi.org/10.1016/j.biocon.2013.11.021

Merow, C., Smith, M. J., \& Silander, J. A. (2013). A practical guide to MaxEnt for modeling species' distributions: What it does, and why inputs and settings matter. Ecography, 36(10), 1058-1069. https:// doi.org/10.1111/j.1600-0587.2013.07872.x

Milanesi, P., Rocca, F. D., \& Robinson, R. A. (2020). Integrating dynamic environmental predictors and species occurrences: Toward true dynamic species distribution models. Ecology and Evolution, 10(2), 1087-1092. https://doi.org/10.1002/ece3.5938

Moreira Rios, A. B., França de Souza, M., \& Blamires, D. (2020). Ocorrência de Anodorhyncus hyacinthinus em Iporá, estado de Goiás. Brasil. Reiva Revista, 3(3), 1-7.

Muscarella, R., Galante, P. J., Soley-Guardia, M., Boria, R. A., Kass, J. M., Uriarte, M., \& Anderson, R. P. (2014). ENMeval: An R package for conducting spatially independent evaluations and estimating optimal model complexity for Maxent ecological niche models. Methods in Ecology and Evolution, 5(11), 1198-1205. https://doi. org/10.1111/2041-210X.12261

Pack, S. M., Ferreira, M. N., Krithivasan, R., Murrow, J., Bernard, E., \& Mascia, M. B. (2016). Protected area downgrading, downsizing, and degazettement (PADDD) in the Amazon. Biological Conservation, 197, 32-39. https://doi.org/10.1016/j.biocon.2016.02.004

Pebesma, E. (2018). Simple features for R: standardized support for spatial vector data. The $R$ Journal, 10(1), 439-446. https://doi. org/10.32614/RJ-2018-009

Phillips, S. J., Anderson, R. P., Dudík, M., Schapire, R. E., \& Blair, M. E. (2017). Opening the black box: An open-source release of Maxent. Ecography, 40(7), 887-893. https://doi.org/10.1111/ecog.03049

Phillips, S. J., \& Dudík, M. (2008). Modeling of species distributions with Maxent: New extensions and a comprehensive evaluation. Ecography, 31(2), 161-175. https://doi.org/10.1111/j.0906-7590.2008.5203.x

Pinho, J. B., \& Nogueira, F. M. B. (2003). Hyacinth Macaw (Anodorhynchus hyacinthinus) reproduction in the northern Pantanal, Mato Grosso, Brazil. Ornitologia Neotropical, 14, 29-38.

Pizo, M. A., Donatti, C. I., Guedes, N. M. R., \& Galetti, M. (2008). Conservation puzzle: Endangered hyacinth macaw depends on its nest predator for reproduction. Biological Conservation, 141(3), 792796. https://doi.org/10.1016/j.biocon.2007.12.023

Presti, F. T., Guedes, N. M. R., Antas, P. T. Z., \& Miyaki, C. Y. (2015). Population genetic structure in Hyacinth Macaws (Anodorhynchus hyacinthinus) and identification of the probable origin of confiscated individuals. Journal of Heredity, 106(S1), 491-502. https://doi. org/10.1093/jhered/esv038

Radeloff, V. C., Dubinin, M., Coops, N. C., Allen, A. M., Brooks, T. M., Clayton, M. K., Costa, G. C., Graham, C. H., Helmers, D. P., Ives, A. R., Kolesov, D., Pidgeon, A. M., Rapacciuolo, G., Razenkova, E., Suttidate, N., Young, B. E., Zhu, L., \& Hobi, M. L. (2019). The Dynamic Habitat Indices (DHIs) from MODIS and global biodiversity. Remote Sensing of Environment, 222, 204-214. https://doi.org/10.1016/j. rse.2018.12.009

Richardson, D. M., \& Whittaker, R. J. (2010). Conservation biogeography - foundations, concepts and challenges. Diversity and Distributions, 16(3), 313-320. https://doi.org/10.1111/j.1472-4642.2010.00660.x

Roberts, D. R., Bahn, V., Ciuti, S., Boyce, M. S., Elith, J., Guillera-Arroita, G., Hauenstein, S., Lahoz-Monfort, J. J., Schröder, B., Thuiller, W., Warton, D. I., Wintle, B. A., Hartig, F., \& Dormann, C. F. (2017).
Cross-validation strategies for data with temporal, spatial, hierarchical, or phylogenetic structure. Ecography, 40(8), 913-929. https://doi. org/10.1111/ecog.02881

Rodriguez, R. D. G., Scanlon, B. R., King, C. W., Scarpare, F. V., Xavier, A. C., \& Pruski, F. F. (2018). Biofuel-water-land nexus in the last agricultural frontier region of the Brazilian Cerrado. Applied Energy, 231, 1330-1345. https://doi.org/10.1016/j.apenergy.2018.09.121

Scherer-Neto, P., Robaldo Guedes, N., \& Barbosa Toledo, M. (2019). Long-term monitoring of a hyacinth macaw Anodorhynchus hyacinthinus (Psittacidae) roost in the Pantanal, Brazil. Endangered Species Research, 39, 25-34. https://doi.org/10.3354/esr00954

Sclater, P. L., \& Salvin, O. (1867). List of birds collected by Mr Wallace on the Lower Amazons and Rio Negro. Proceedings Zoological Society of London, 35(1), 566-596.

Shaney, K. J., Wostl, E., Hamidy, A., Kurniawan, N., Harvey, M. B., \& Smith, E. N. (2017). Conservation challenges regarding species status assessments in biogeographically complex regions: Examples from overexploited reptiles of Indonesia. Oryx, 51(4), 627-638. https:// doi.org/10.1017/S0030605316000351

Sullivan, B. L., Aycrigg, J. L., Barry, J. H., Bonney, R. E., Bruns, N., Cooper, C. B., Damoulas, T., Dhondt, A. A., Dietterich, T., Farnsworth, A., Fink, D., Fitzpatrick, J. W., Fredericks, T., Gerbracht, J., Gomes, C., Hochachka, W. M., lliff, M. J., Lagoze, C., La Sorte, F. A., ... Kelling, S. (2014). The eBird enterprise: An integrated approach to development and application of citizen science. Biological Conservation, 169, 31-40. https://doi.org/10.1016/j.biocon.2013.11.003

Syfert, M. M., Joppa, L., Smith, M. J., Coomes, D. A., Bachman, S. P., \& Brummitt, N. A. (2014). Using species distribution models to inform IUCN Red List assessments. Biological Conservation, 177, 174-184. https://doi.org/10.1016/j.biocon.2014.06.012

Tella, J. L., Hiraldo, F., Pacífico, E., Díaz-Luque, J. A., Dénes, F. V., Fontoura, F. M., Guedes, N., \& Blanco, G. (2020). Conserving the diversity of ecological interactions: The role of two threatened macaw species as legitimate dispersers of "Megafaunal" fruits. Diversity, 12(2), 45. https://doi.org/10.3390/d12020045

Thornhill, A. H., Baldwin, B. G., Freyman, W. A., Nosratinia, S., Kling, M. M., Morueta-Holme, N., Madsen, T. P., Ackerly, D. D., \& Mishler, B. D. (2017). Spatial phylogenetics of the native California flora. BMC Biology, 15(1), 96. https://doi.org/10.1186/s12915-017-0435-x

Tjur, T. (2009). Coefficients of determination in logistic regression models-A new proposal: The coefficient of discrimination. The American Statistician, 63(4), 366-372. https://doi.org/10.1198/ tast.2009.08210

UNEP-WCMC \& IUCN (2019). The World Database on Protected Areas (WDPA). UNEP-WCMC \& IUCN. www.protectedplanet.net

Vellend, M., \& Kharouba, H. M. (2013). Setting conservation priorities when what you see is not what you get. Animal Conservation, 16(1), 14-15. https://doi.org/10.1111/acv.12023

Weber, M. M., Stevens, R. D., Diniz-Filho, J. A. F., \& Grelle, C. E. V. (2017). Is there a correlation between abundance and environmental suitability derived from ecological niche modelling? A meta-analysis. Ecography, 40(7), 817-828. https://doi.org/10.1111/ecog.02125

Whittaker, A. (2009). Pousada Rio Roosevelt: A provisional avifaunal inventory in south-western Amazonian Brazil, with information on life history, new distributional data and comments on taxonomy. Cotinga, 31, 23-46.

Wisz, M. S., Hijmans, R. J., Li, J., Peterson, A. T., Graham, C. H., Guisan, A., \& Group, N. P. S. D. W (2008). Effects of sample size on the performance of species distribution models. Diversity and Distributions, 14(5), 763-773. https://doi.org/10.1111/j.1472-4642.2008.00482.x

Yamashita, C. (1997). Anodorhynchus macaws as followers of extinct megafauna: An hypothesis. Ararajuba, 5(2), 176-182.

Yamashita, C., \& de Valle, M. P. (1993). On the linkage between Anodorhynchus macaws and palm nuts, and the extinction of the Glaucous Macaw. Bulletin of the British Ornithologists' Club, 113(1), 53-60. 
Zuckerberg, B., Fink, D., Sorte, F. A. L., Hochachka, W. M., \& Kelling, S. (2016). Novel seasonal land cover associations for eastern North American forest birds identified through dynamic species distribution modelling. Diversity and Distributions, 22(6), 717-730. https:// doi.org/10.1111/ddi.12428

Zurell, D. (2017). Integrating demography, dispersal and interspecific interactions into bird distribution models. Journal of Avian Biology, 48(12), 1505-1516. https://doi.org/10.1111/jav.01225

\section{BIOSKETCH}

Christian Devenish works in spatial ecology, with a focus on estimating species' occurrences and abundances, their relationships with environmental factors, including remote-sensed predictors. His research has strong practical applications for conservation, including land use planning, restoration, red listing and priority setting, especially in tropical countries.

\section{SUPPORTING INFORMATION}

Additional supporting information may be found online in the Supporting Information section.

How to cite this article: Devenish, C., Lees, A. C., Collar, N. J., \& Marsden, S. J. (2021). Multi-decadal land use impacts across the vast range of an iconic threatened species. Diversity and Distributions, 00, 1-13. https://doi.org/10.1111/ ddi.13395 